Mississippi ; and if you dare to jump one of my claims, die yon must. My name is Simeon Cragin, Sir, all the way from Bangor, and you must leave these diggings, with but few remarks." The increasing rage of "Simeon" became alarming to the young Sucker, and he found the shortest road possible to the State of Illinois, and we presume has never since visited Iowa with a view at least of "jumping claims."

There are also many striking reminiscences of the Indians and their sojourn, both before and after the whites took possession of the country, that might be interesting, and may be added hereafter. There are those now living in Le Claire who remember with what satisfaction the Indians often returned to their forest home at the head of the rapids. In 1837, over one thousand were encamped where the city now stands.

$$
\text { [TO BE CONTINUED.] }
$$

\title{
LETTER OF THE LATE COL. W. M. G. TORRENCE.
}

[The following copy of a letter of the late Col. Torience, of Keokuk, Iowa, relating to two flags carried by his regiment, and presented to the State Historical Society, will be read with interest. A memoir of this much lamented officer may be expected in a future number of the Annals.]-EDITor.

$$
\begin{aligned}
& \text { Headquarters 30th Iowa Volunteers, } \\
& \text { ItKa, Miss., Oct. 13th, } 1863 \text {. }
\end{aligned}
$$

N. B. BAKER, Adj't Gen'l State of Iowa :

Sir :-Accompanying this, you will receive two Flags, worn out in the service. They were carried by the 30th Iowa during their marches, a distance of five thousand seven hundred miles, between the 26th of October, 1862, and the 10th of $\mathrm{Oc}$. tober, 1863.

They were carried in the following named Battles, to wit:

Chickasaw Bayou, December 28th and 29th, 1862.

Arkansas Post, January 10th and 11th, 1863.

Jackson, Miss., May 14th, 1863.

Seige of Vicksburg, from May 18th to July 4th, 1863.

Clinton, Miss., July 11th, 1863.

Jackson, Miss., July 12th, 13th, 14th, and 15th, 1863.

Brandon, Miss., July 18th, 1863. 
It is the wish of the Regiment that you forward them to the State Historical Society, there to be retained subject to the order of the Commanding Officer of the Regiment.

Respectfully, your obedient servant,

W. M. G. TORRENCE,

Colonel Commanding.

Copy : N. B. BAKER, Adj't Gen'l of Iowa.

\section{OFFICERS OF THE STATE HISTORICAL SOCIETY FOR 1864.}

President-His Excellency, Sam'l J. Kirkwood, of Iowa City.

Vice Presidents-Hon. G. W. McCleary, Pres. O. M. Spencer, D. D., Hon. F. H. Lee-all of Iowa City ; Willard Barrows, Esq., of Davenport; Capt. H. B. Horne, of Bloomfield; and Col. Wm. M. Stone, Governor elect, of Des Moines.

Corresponding Secretary and Librarian-Prof. T. S. Parvin, of Iowa City.

Recording Secretary-James W. Morrison, of Iowa City. Treasurer-J. P. Wood, of Iowa City.

Board of Curators-Pres. O. M. Spencer, D. D., Rev. M. S. Osmond, Hon. F. H. Lee, G. H. Jerome, Esq., J. P. Wood, Esq., Hon. G. W. McCleary, Prof. Jas. T. Roberts, D. D., William Crum, Esq., I. N. Jerome, Esq., Prof. N. R. Leonard, Rev. S. S. Howe, J. R. Hartsock, Esq., Rev. F. M. Gray-all of towa City; Rev. W. Barris, of Burlington; Hon. Wm. H. Tuthill, of Tipton; Col. H. A. Wiltse, of Dubuque; Hon. J. B. Grinnell, of Grinnell; Hon. E. Price, of Guttenburg.

Comartiee of Publication.-The Committee consists of Oliver M. Spencer, D. D., President of the State University, Chairman, N. R. Leonard, Professor in the State University, and Rev. Samuel Storrs Howe, Acting Editor of the Annals of Iowa.

All communications and subscriptions may be sent to the Editcr of the Annals, Iowa City, Iowa. 
Copyright of Annals of Iowa is the property of State of Iowa, by \& through the State Historical Society of Iowa and its content may not be copied or emailed to multiple sites or posted to a listserv without the copyright holder's express written permission. However, users may print, download, or email articles for individual use. 